Soil Analysis

A Handbook of Physical and Chemical Methods. By C. Harold Wright. Second edition. Pp. $\mathrm{x}+276$. (London: Thomas Murby and Co.; New York: D. Van Nostrand Co. Ine., 1939.) 12s. 6d. net.

7 HE first edition of this book, although written particularly for those who have not the facilities of a good library, proved a useful addition to the bookshelves of most agricultural chemists. In this revised edition the author has replaced methods of analysis that were becoming out of date or of only minor importance by new ones. Some fresh sections have been added dealing with the freezing point, glass electrode, inorganic soil colloids and methods for the determination of cobalt and zinc. To the section on carbon the Ter Meulen dry combustion method has been added, together with a summary of the report of the Organic Carbon Committee of the International Society of Soil Science. This Committee compared a number of methods for determining carbon in soils, and the results and experiences of the analysts should be useful to soil chemists.

In presenting the chemical methods of analysis in his book the author has divided them into general and special methods, but the reviewer suggests that this grouping is not entirely satisfactory, since the ordinary Kjeldahl method for nitrogen and common methods for carbon are to be found under special methods, whereas the determinations of phosphoric acid and potassium appear in the general class. This is only a very minor criticism, and in no way detracts from the value of the book.

R. G. WARREN.

\section{Anthropology aNd ARChatology}

James George Frazer

The Portrait of a Scholar. By R. Angus Downie. Pp. ix + 141. (London: Watts and Co., Ltd., 1940.) 5s. net.

THIS "portrait of a scholar" is drawn by one who now for a number of years has been associated with Sir James Frazer's work. That association has been fruitful in producing the supplementary volumes of "The Golden Bough" and "Totemism", as well as the five volumes of selected extracts from the notebooks which bear testimony to the life-long and unremitting industry which Sir James has devoted to the commendable practice of note-making. A further outcome of this association is that it has given Mr. Downie an acquaintance, intimate and unrivalled, with the lines of every branch of investigation upon which Sir James has brought his genius to bear, as well as a clear insight into the working of his mind, so far as that is possible when dealing with a subject who both as an individual and as author exhibits in a supreme degree the scholar's qualities of balance and restraint.

Sir James Frazer's life-history is the story of his work ; and he lives in his books. For the benefit of those who may know but little of that work, who perhaps have come into touch with only one aspect of it, or indeed may not know it at all, Mr. Downie has sketched a portrait of a many-faceted mind, and of what, had Sir James been a man of action, would have been termed justly a life of adventure in many fields. For in the realms of the mind Sir James has been a traveller in many remote tracts and untrodden ways, a pioneer and explorer in the dark ways of humanity. Chapter by chapter, Mr. Downie guides the reader, assisting his steps with illuminating quotation, from Sir James's early work at Cambridge and his association with Robertson Smith to "The Golden Bough", to "Totemism" and to "The Folklore of the Old Testament", to name the more important only among his monumental contribution to the comparative study of the human mind, its beliefs and the institutions to which it gives rise. But these, though the best known, do not complete the tale of his activities. In addition, there are the classical studies by which he first earned his right of entry to the learned world and produced his "Pausanias" and the "Fasti" of Ovid, border-line works; and there are also those purely literary studies of Cowper and Addison and the other 'pieces' in which some hold Sir James has risen to the highest point of that stylistic excellence which Mr. Downie rightly stresses throughout.

\section{The Illusion of National Character}

By Hamilton Fyfe. Pp. v+274. (London: Watts and Co., 1940.) 8s. 6d. net.

VR. HAMILTON FYFE sets out to destroy the VI generalizations about peoples-mainly the illusion of national character-which in past and current discussion obscure counsel. While some generalizations about large groups are possible, is it true that general statements about Englishmen, Frenchmen or Germans are valid, apart from affirmation of such externals as membership of a particular State, geographical habitat or language? Is there over and above these such a thing as national character? As will be gathered from his title, in the judgment of the author there is not. Even though he is prepared to concede certain differences due to surroundings, he would maintain that, beneath, these peoples are alike. On this it may be remarked that while this may be true of race in a biological sense and the so-called 'racial theory' a delusion, when it is not a fraud, national character stands in a different category. The cumulative effect of cultural continuity, viewed historically, cannot be ignored ; any attempt to do so will be no less disastrous than the exaggerated nationalism which has brought about the War.

\section{Biology}

Graptolithina

Von O. M. B. Bulman. (Handbuch der Paläozoologie, herausgegeben von $\mathrm{O}$. H. Schindewolf, Lieferung 2, Band 2D.) Pp. iii +92. (Berlin : Gebrüder Borntraeger, 1938.) 13 gold marks.

7 HIS is the first part to be published of a comprehensive treatise on palæozoology. The general plan is similar to that of Zittel's great "Handbuch" (1876-93), but whereas that work was in four volumes 